\title{
Youth and Social Security Coverage in Brazil*
}

\author{
Paulo Tafner ${ }^{1}$, Carolina Botelho ${ }^{2}$ \\ ${ }^{1}$ Institute for Applied Economic Research, Rio de Janeiro, Brazil \\ ${ }^{2}$ Institute for Social and Political Studies Rua da Matriz, Rio de Janeiro, Brazil \\ Email: paulo.tafner@gmail.com, carolinabotelhomch@gmail.com
}

Received 27 September 2013; revised 30 October 2013; accepted 8 November 2013

Copyright (c) 2014 Paulo Tafner, Carolina Botelho. This is an open access article distributed under the Creative Commons Attribution License, which permits unrestricted use, distribution, and reproduction in any medium, provided the original work is properly cited. In accordance of the Creative Commons Attribution License all Copyrights (C) 2014 are reserved for SCIRP and the owner of the intellectual property Paulo Tafner, Carolina Botelho. All Copyright @ 2014 are guarded by law and by SCIRP as a guardian.

\section{Abstract}

Brazil is still a young country, just starting the process of aging, but Brazil's spending on social security is similar to those countries whose population aging has already occurred. Some studies explain the high cost of the Brazilian Social Security System due to the assumption that there is a positive relationship between social security and poverty alleviation. In fact, the effectiveness of this instrument as reducing poverty was high until 2002, but stopped growing and fell slightly thereafter. Brazilian law provides that wives and children or stepchildren under age 21, or under 25 , since they are college students, are welfare beneficiaries. In other words they are protected by Brazilian Social Security System. However, data reveals that in Brazil, children and young people have a very low social security direct coverage, which increases with age and reaches high levels for individuals aged 60 or older. Children and young people are the groups most affected by poverty and extreme poverty in Brazil. In this sense, the assumption according to which Social Security helps combat family poverty is flawed. Considering these issues, this article aims to contribute to the debate on the need to rethink the Brazilian Social Security System and the need of construction of specific policies for children and young people in Brazil.

\section{Keywords}

Social Security in Brazil; Youth; Poverty and Public Policy

\section{Introduction}

Two of the most frequent concerns of the Brazilian Social Welfare analysts are the relatively low rate of pension

"The authors thank to Rafael Erbisti for preparing figures and tables. 
coverage and high and persistent rate of non-contributory membership. These phenomena, of course, are not restricted to Brazil and they are in fact characteristic features of many developing countries, such as many Latin American countries as well as several African countries.

These two indicators of the amplitude of the social security system, although often been treated as synonyms, are of different natures, determined by different factors and also differently affect particular groups-though sometimes the same individual is subject to both. At last, they usually cause different effects in terms of fairness and justice.

The social security coverage here named as pension coverage, in broad terms, refers to the many ways of social protection that an individual may get. Contribution to social security is solely one of these forms. All those who receive social security benefits are covered (protected) by the social security system, even though they have not been in the past a contributor for the Brazilian social pension. In 2011, for example, 7 of every 10 Brazilians had social protection, while less than $47 \%$ of individuals of working age were social security contributors.

First, it is necessary to make clear that when an individual, and also his or her offspring, are protected by social security. However, in Brazil, more than $50 \%$ of people of working age do not contribute to social foresight and thus have no pension coverage. Consequently, their children are not protected as well. This phenomenon, as will be seen below, is particularly evident in groups of young adults that live in young families. Their children are still young and are not able to get job either income. Besides being a serious lack of social protection for a significant portion of our society, this phenomenon also produces two highly undesirable effects: the first, is that it limits the financing capacity of the system requiring high burden on the set of social security taxpayers (workers and firms) - with obvious impacts on the cost of labor and the prices of our products; the second is that it produces - given the current rules of access and fixing the of benefit's value-a numerous contingent of individuals who have never contribute to the social security will receive in the future benefits with no contribution. This means that people who are in this situation now will receive in the future social benefits whose values will be equal to those who throughout their working lives contributed for social security, thus creating an inequality in relation to the conditions for obtaining welfare income.

The paper is divided into four sections, besides this introduction. The second section presents Brazilian social security system in figures and offers some international comparisons. In the third, it presents and discusses various ways of measuring pension coverage and also the evolution of these measures in Brazil in the 1982-2011 period. In the fourth section, these measures are presented according to different attributes of coverage, in which there is a highlight of the significantly low coverage for children, youth and young adults. The final section provides the main conclusions.

\section{An Overview of Brazilian Social Security}

The Brazilian pension system had its current institutional design set from the 1988 Constitution. Since then, the system has gone through two constitutional reforms (CA 20/1998 and CA 41/2003) and regulations resulting from these reforms. In particular, Law No. 8213 of 24/07/1991 defines and regulates the Benefit Plan of Social Security and Law No. 8.742, of December 7, 1993 (Organic Law of Social Assistance-LOAS), states that, in Brazil, the social assistance is a citizen's right and a duty of the State. As a policy of social security non-contributory, the Brazilian social assistance should ensure minimum income and must be accomplished through an integrated set of initiatives by government and by society, to ensure the provision of basic needs of the population $^{1}$.

The system is divided into two regimes. The first one is the General Regime of Social Security (RGPS administered by INSS). It manages the pension system for private sector workers and monthly pays something close to 23.5 million benefits. The second regime manages the Pension Plan for civil servant of the three levels of government, and each level has its own plan (RPP). Within the Union, the RPP monthly pays something slightly more than 1 million benefits. The military staff has specific plans. Table 1 presents, for 2009-2012, the revenue of social security contributions and the expenditure on retirees and pensioners and other welfare benefits, separating the information for each of the schemes.

These statistics may bring up an equivocal idea that the main problem of fiscal sustainability of Social Security is located in the public sector system. A detailed analysis, however, leads us to the opposite conclusion. Al-

${ }^{1}$ For a detailed description, see "Statistical Yearbook of Social Security—Historical Supplement”, MPAS. 2011. 
though it is still high the deficit in public sector system, this result reflects the rules before the 1998 and 2003 reforms. The high imbalance stems from the fact that there are a significant number of civil servants who retired according to the old rules which were much less restrictive. This situation has been structurally modified after the two reforms mentioned. This clearly can be seen from data presented in Figure 1.

Data shows that since 1991, the expense of RPP grew consistently until 1994-95, as a result of the implementation of constitutional precept, but it remained stable since then. The same, however, did not happen with the INSS spending which increased throughout the period, except in 2008 and 2010 when GDP grew at very high rates. This expenditure increased from 3.4\% of GDP in 1994 to $7.2 \%$ in 2012 and is now the major expense of the federal budget.

Three combined factors have contributed to the RGPS's spending performance: a) less restrictive rules for pension and retirement in the face of changing demographics of the country, b) the effect of minimum wage adjustments since the mid-90's, and c) low GDP average growth. Besides those, for the future, a fourth component will have a decisive role: the demographic dynamics (see Figure A1 in the Annex). As announced by the IBGE, with revisions made in 2008, the country will face an accelerated aging process in the next 30 years, imposing challenges to our social security system and to public finances as well.

It must be pointed out that in Brazil the pension system is modeled as a PAYG (pay-as-you-go), i.e., the current productive generation supports the benefits to the generation that has retired in the past and believes that

\begin{tabular}{ccccc}
\hline Table 1. Social security balance: 2009 throughout 2012 (\% of GDP). \\
\hline Social security system & 2009 & 2010 & 2011 & 2012 \\
\hline Civil servant & $\mathbf{- 1 . 7}$ & $\mathbf{- 1 . 7}$ & $\mathbf{- 1 . 6}$ & $\mathbf{- 1 . 6}$ \\
Revenues & 0.3 & 0.3 & 0.3 & 0.3 \\
Expenditures & 2.0 & 2.0 & 1.9 & 1.8 \\
INSS & $\mathbf{- 1 . 4}$ & $\mathbf{- 1 . 5}$ & $\mathbf{- 0 . 9}$ & $\mathbf{- 0 . 9}$ \\
Revenues & 5.8 & 5.8 & 5.9 & 6.3 \\
Expenditures & 7.2 & 7.3 & 6.8 & 7.2 \\
Total & $-\mathbf{3 . 1}$ & $-\mathbf{3 . 2}$ & $-\mathbf{2 . 5}$ & $-\mathbf{2 . 5}$ \\
Revenues & 6.1 & 6.1 & 6.2 & 6.5 \\
Expenditures & 9.2 & 9.3 & 8.7 & 9.0 \\
\hline
\end{tabular}

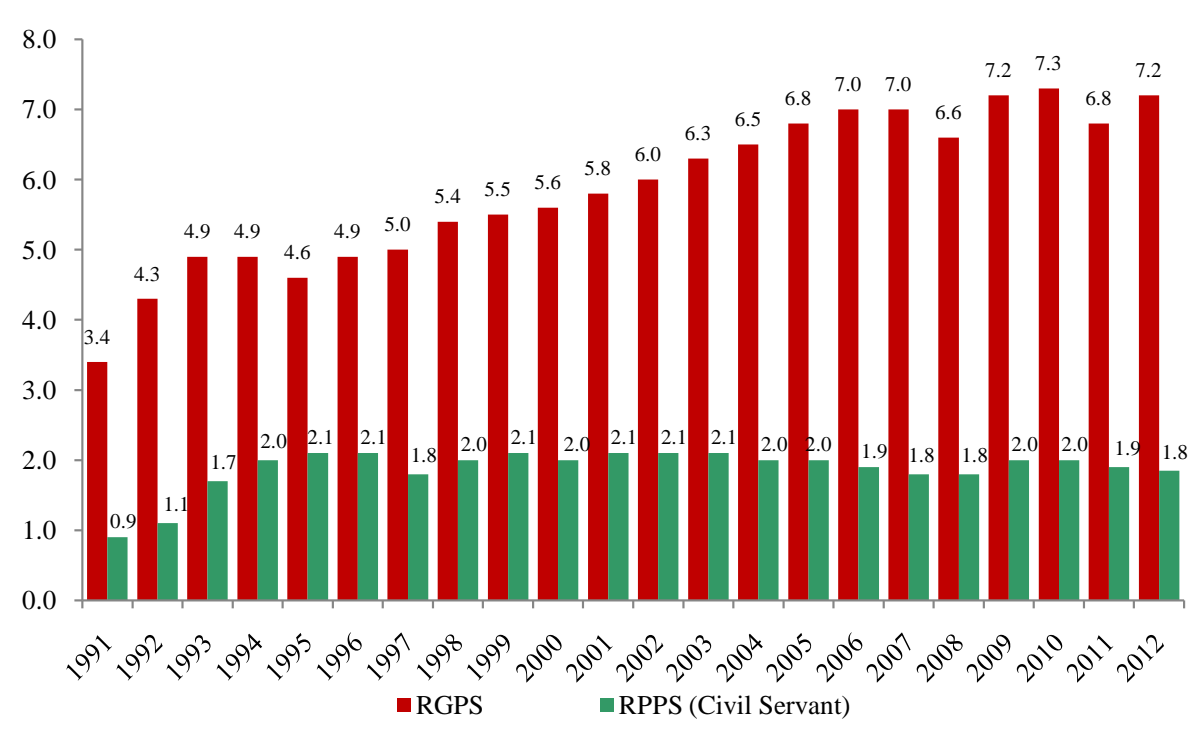

Figure 1. RGPS and RPPS expenditures on benefits (as \% of GDP), Source: MPOG, MPAS, STN. 
will be funded by a new generation in the future. Given the demographic conditions the Brazilian social security exposes all their fragility since now, when we are still young the social security system presents structural deficits. How to bet on the logic of intergenerational solidarity if one that is now a contributor has no institutional safeguards that your efforts will be compensated in the future? And how to solve the issue if nowadays people live longer than in the past and there is a large portion of informal working? According to Giambiagi and Tafner [1], "If the parameters that govern the system are well calibrated and if there are no significant changes in the demographic dynamics or restrictions on the labor market, it is possible that the system will survive without serious imbalances and no deficits or fiscal pressure. But what if it does not?"

Taking data from 1990 to 2011, it is observed that the volume of granting new benefits has grown at an average annual rate quite high. Table 2 presents, for selected years, the amount of benefits provided by Social Security. It is noteworthy that the average growth of granting full benefits of Social Security between 1990 and 2011was 6.04\% per year in the period. The pension benefits granted in the same period was 5.96\% per year, and retirement benefits granted grew at an annual rate of $4.74 \%$. It is also important to mention that the elderly population in the same period, increased from 9.897 million individuals in 1990 to 23.536 million in 2011, equivalent to an average annual growth rate of only $4.21 \%$, slightly more than the pace of granting pension benefits and $11 \%$ lower than the pace of retirement benefits.

The growth of the INSS spending was also a result of "price effect", in others words, the adjustment of pension benefits. For the period between 1994 and 20011 (the period for which detailed data are available), Table 3 shows the real value of benefits issued by the INSS (deflated by INPC annual). It is noteworthy that, in just 17 years, spending on social security benefits were doubled, especially those on retirement and survivor pension have increased in real terms. In virtually all groups of benefits the real spending growth rate was higher than the increase in the number of issued benefits, reflecting the adjustment of the real value of the benefit in the period.

It seems clear that the Brazilian social security system showed high growth, in the number of contributors, in the number of beneficiaries-increasing as consequence the membership contribution and pension coverage-, and in the level of expenditure. The expenditures are very high compared to other countries, even having a still young population, as shown in Figure 2.

Table 2. Number of granted benefits-social security: 1990-2011.

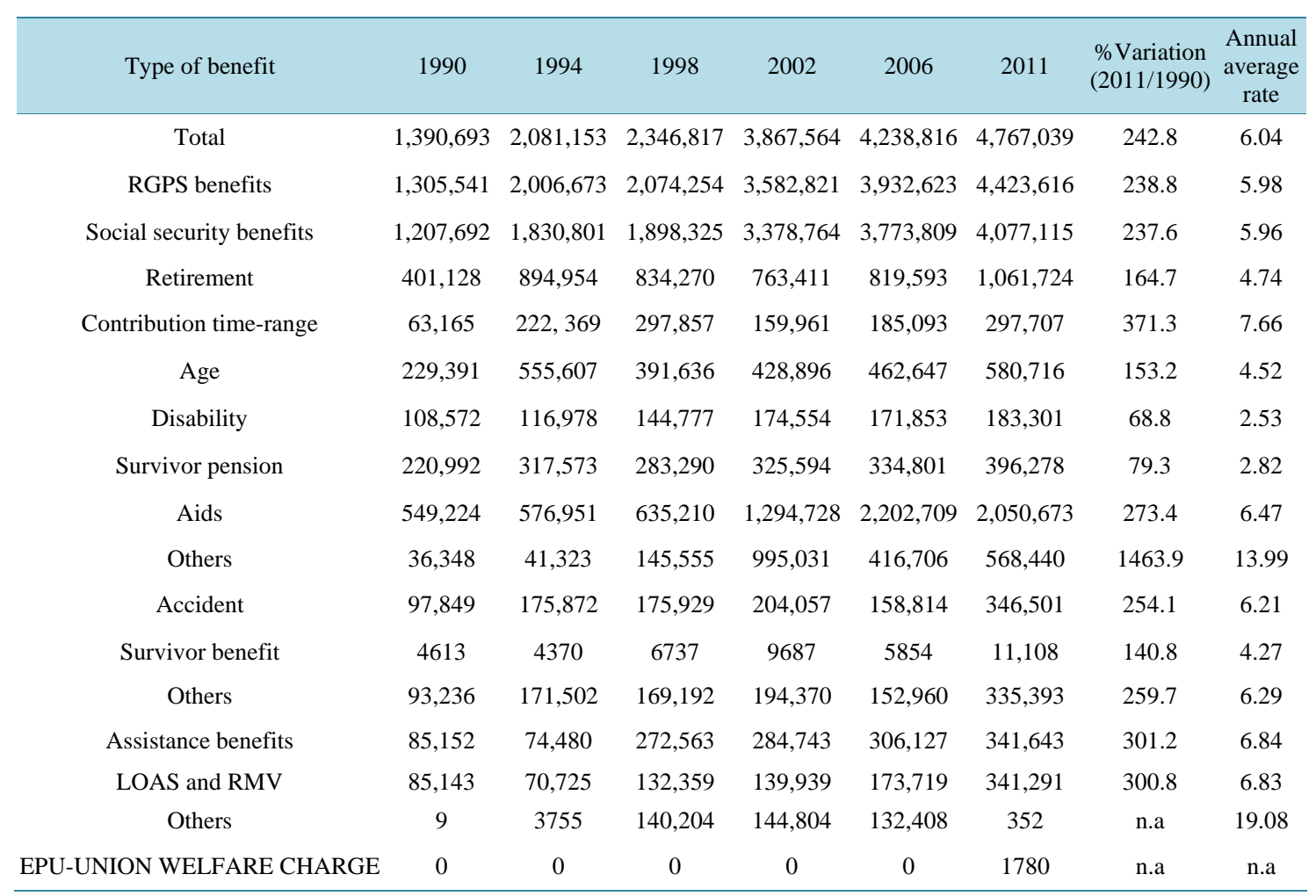

Source: AEPS—Historical Supplement, 2011. 
Table 3. Issued benefit's value-INSS: 1994-2011 (In R\$ million position in December, selected years)/a.

\begin{tabular}{cccccccc}
\hline Type of benefit & 1994 & 1998 & 2002 & 2006 & 2011 & $\begin{array}{c}\text { Variation \% } \\
(2011 / 1994) \text { Average rate }\end{array}$ \\
\hline Total & 6445 & 10,394 & 12,174 & 16,635 & 21,200 & 228.9 & 7.26 \\
RGPS benefits & 6023 & 9820 & 11,414 & 15,258 & 19,076 & 216.7 & 7.02 \\
Social security benefits & 5846 & 9495 & 11,0332 & 14,809 & 18,512 & 216.7 & 7.02 \\
Retirement & 4160 & 6925 & 7606 & 9909 & 12,761 & 206.8 & 6.82 \\
Contribution time-range & 2019 & 4134 & 4182 & 4829 & 5967 & 195.5 & 6.58 \\
Age & 1488 & 1911 & 2303 & 3387 & 4668 & 213.8 & 6.96 \\
Disability & 653 & 880 & 1121 & 1694 & 2125 & 225.5 & 7.19 \\
Survivor pension & 1472 & 2233 & 2718 & 3618 & 4654 & 216.2 & 7.01 \\
Aids & 199 & 324 & 625 & 1263 & 1060 & 433.0 & 10.34 \\
Others & 16 & 13 & 83 & 18 & 37 & 133.5 & 5.11 \\
Accident & 177 & 325 & 381 & 449 & 565 & 218.3 & 7.05 \\
Survivor benefit & 36 & 65 & 89 & 124 & 158 & 343.6 & 9.16 \\
Others & 142 & 260 & 292 & 325 & 406 & 186.8 & 6.39 \\
Assistance benefits & 421 & 575 & 760 & 1364 & 2109 & 400.4 & 9.93 \\
LOAS and RMV & 415 & 563 & 748 & 1351 & 2094 & 404.1 & 9.98 \\
Others & 12 & 12 & 13 & 15 & 142.2 & 5.34 \\
\hline EPU-UNION WELFARE CHARGES & 0 & 0 & 0 & 14 & 15 & n.a & n.a \\
\hline
\end{tabular}

Source: AEPS—Historical Supplement, 2011. /a: Deflated by INPC.

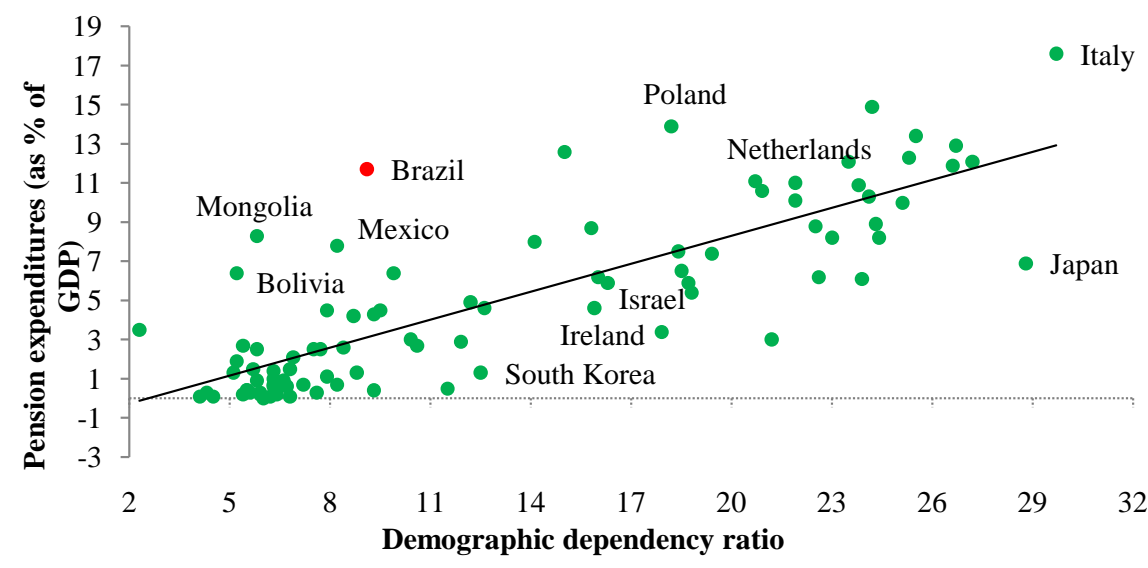

Figure 2. Pension expenditures (as \% of GDP) - sample of 90 countries, Source: World Bank data base.

The literature has treated the social security coverage as the ratio of individuals who are affiliated to the pension scheme and the employed population. Membership can be given in several ways, and even simultaneously. A traditional way to measure coverage is through the relative incidence of contributors to the system. Before take care of this issue we present an international overview on coverage. In 1994, the World Bank prepared the report "Averting the Old Age Crisis: Policies to Protect the Old and Promote Growth.” In it are available data on pension coverage for more than sixty countries. Table 4 presents the data for some selected countries. 
In the overall, Brazil is located in the upper third of higher coverage countries, but at a level lower than that observed for developed countries and even for some of Latin American countries.

Comparing data from two different years in Brazil (2011 and 1988) on social security contribution of working age population (15 - 59 years) one can see that in 2011 this rate was $15 \%$ higher than in 1988, having increased just over 6 percentage points. Although modest, this result is very expressive, because in the same period the working age population increased its size by almost 50\%. This means that even pressured by demographic effect, the labor market and Social Security institutional improvements contributed to increase contributory membership. Table 5 presents the data on contributory membership and pension coverage.

Spite the contribution rate be an important indicator of the social security performance, the social security coverage however, as stated earlier, seems to be a more appropriate measure of the extent of the pension system. It can occur either by contribution or by receiving regular benefits. Between 1984 and 2011 (Table 5), pension coverage rose by almost 5 percentage points, reaching in 2011 almost 3/4 of the population.

Between 1984 and 2011, the expansion of total social security coverage was 5.4 percentage points. At same time, for the elderly segment (individuals aged 65 or more) this rose from $90.2 \%$ to $94.41 \%$. However, this performance was not accompanied by young population. In fact, the pension coverage for young people was slightly reduced from 60\% in 1984 to 59.6\% in 2011. Another issue that must be pointed out is that in Brazil we still have $28 \%$ of the population that is not covered by social security.

\section{The Social Security Coverage in Brazil-Recent Years}

\subsection{The Direct Social Security Coverage: Definitions}

The direct social security coverage ${ }^{2}$ is a result of the individual insertion in the welfare system. This insertion can basically be done by two different forms: by receiving regular benefits, such as retirement, pension or BPC-LOAS or by contributing to the pension system. So, the person who receive a benefit from welfare system or contribute to welfare system will be considered as directly protected by welfare system.

\begin{tabular}{ccccccccc}
\multicolumn{7}{c}{ Table 4. Social security coverage (in \%)-many countries. } \\
\hline Country & Year & Coveragee & Country & Year & Coveragee & Country & Year & Coveragee \\
\hline Argentina & 1989 & $53.2 \%$ & India & 1990 & $10.6 \%$ & Senegal & 1990 & $6.9 \%$ \\
Bolivia & 1992 & $11.7 \%$ & Indonesia & 1991 & $10.7 \%$ & South Korea & 1991 & $30.0 \%$ \\
Brazil & 2004 & $49.7 \%$ & Jamaica & 1991 & $39.3 \%$ & Spain & 1992 & $85.3 \%$ \\
Burkina Faso & 1989 & $3.7 \%$ & Japan & 1989 & $100.0 \%$ & Sri Lanka & 1990 & $28.8 \%$ \\
Cameron & 1989 & $13.7 \%$ & Kenya & 1990 & $14.7 \%$ & Sweden & 1990 & $100.0 \%$ \\
Canada & 1989 & $97.4 \%$ & Malaysia & 1991 & $48.7 \%$ & Switzerland & 1992 & $97.4 \%$ \\
Chile & 1992 & $55.7 \%$ & México & 1990 & $37.9 \%$ & Taiwan & 1988 & $86.7 \%$ \\
Colombia & 1989 & $23.9 \%$ & Mozambique & 1986 & $0.2 \%$ & Tanzania & 1990 & $5.1 \%$ \\
Costa Rica & 1993 & $54.2 \%$ & Niger & 1990 & $2.8 \%$ & Turkey & 1990 & $34.6 \%$ \\
Denmark & 1990 & $100.0 \%$ & Nigeria & 1990 & $2.4 \%$ & United Kingdom & 1990 & $94.2 \%$ \\
Dominican Republic & 1988 & $11.5 \%$ & Pakistan & 1989 & $3.5 \%$ & Uruguay & 1989 & $68.8 \%$ \\
Ecuador & 1989 & $37.8 \%$ & Panamá & 1990 & $39.6 \%$ & USA & 1989 & $96.9 \%$ \\
Egypt & 1989 & $62.3 \%$ & Peru & 1992 & $25.7 \%$ & Venezuela & 1990 & $34.3 \%$ \\
Ghana & 1989 & $13.3 \%$ & Philippines & 1990 & $19.1 \%$ & Zambia & 1989 & $13.8 \%$ \\
Honduras & 1990 & $18.7 \%$ & Ruanda & 1989 & $9.3 \%$ & & & \\
\hline
\end{tabular}

Source: World Bank (2004).

\footnotetext{
${ }^{2}$ The coverage rate is expressed by a ratio. The numerator is the sum of individuals who contribute to social security, of individuals receiving retirement benefit and of individuals who receive the pension benefit. The denominator is the population.
} 


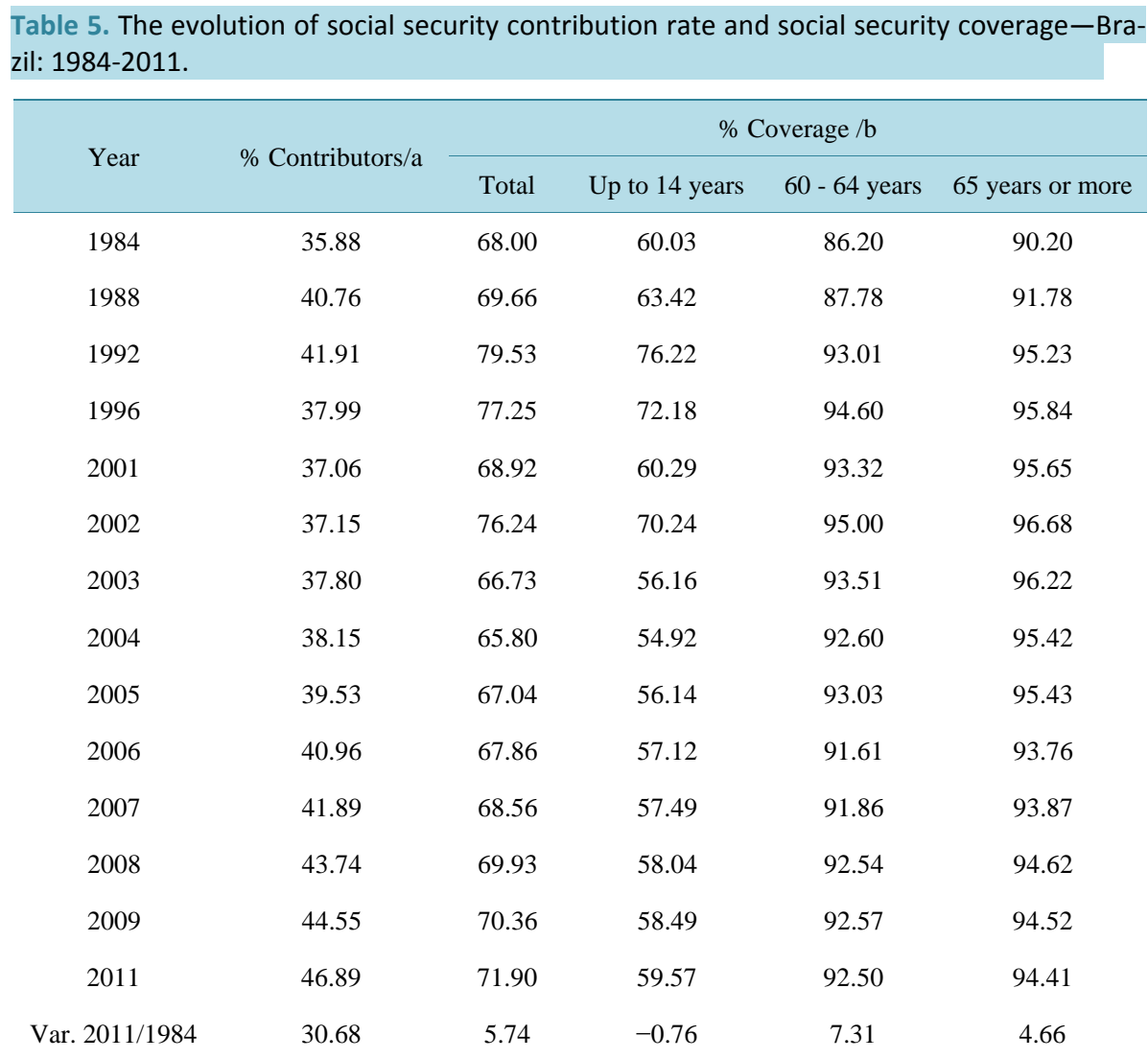

/a: expressed in percentage of population age 15 to 59 years. /b: expressed in percentage of all population. Source: National Household Sample Survey (Pnad)/IBGE, several years.

For the calculation of this statistic we use the Pnad. Although the coverage of Pnad for topics related to social security is less than in administrative records, their distribution is very similar to that observed in the records of the Ministry of Social Welfare (MPAS), the responsible agency for the management and control of information on social welfare.

\subsection{The Total Social Security Coverage: The Evidence}

Besides the usual way to calculate the coverage of social security, as stated above, there are many others to measure it. All of them can be calculated and they express the magnitude of the social security system. As we said, in Brazil, an individual will have direct welfare coverage if he pays the social security fees, or he receives a benefit from INSS (retirement or a survivor benefit).

Using data from several Pnads (between 1982 and 2011) it is observed a consistent growing on direct social security coverage rate and it happened in all of its forms, as can be seen in Table 6 . The direct pension coverage rate has grown from $26.53 \%$ in 1982, to $41.94 \%$ in 2011 . This increase in the direct coverage occurred with the expansion of social security coverage in all its forms: by contributing and by receiving benefits. This performance however was not homogeneous. At the bottom of Table 6 one can find the rates of change between 1982 and 2011 and between 1988 and 2011.

In the period, the direct coverage as a whole has expanded by $58.05 \%$. The portion due to retirement benefits grew $87.23 \%$, those due to pension benefits grew $131.11 \%$. But those due to contributory membership grew solely $45.54 \%$. Taken the post-Constitution period, the numbers are lower: $39.09 \%, 65.59 \%, 75.45 \%$ and $29.39 \%$, respectively. Symmetrically, the rate of non-coverage fell by 15.4 percentage points, which represents a decrease of $20.96 \%$ in the whole period and $16.87 \%$ in the post-Constitution.

Nevertheless there is a wide variation between regions, either in the levels of coverage for each specific type or in the pace at which rates vary in time. Southeast and especially the South, present higher coverage rates in all 
Table 6. Direct social security coverage-Brazil: 1982-2011 (selected years).

\begin{tabular}{cccccc}
\hline Year & $\begin{array}{c}\text { Coverage by } \\
\text { retirement }\end{array}$ & $\begin{array}{c}\text { Coverage } \\
\text { by pension }\end{array}$ & $\begin{array}{c}\text { Coverage } \\
\text { by contribution }\end{array}$ & $\begin{array}{c}\text { Total direct } \\
\text { coverage }\end{array}$ & $\begin{array}{c}\text { Not direct } \\
\text { coverage }\end{array}$ \\
\hline 1982 & 5.01 & 1.44 & 20.09 & 26.53 & 73.47 \\
1985 & 5.35 & 1.65 & 20.35 & 27.35 & 72.65 \\
1988 & 5.67 & 1.89 & 22.59 & 30.15 & 69.85 \\
1990 & 5.91 & 2.23 & 26.39 & 34.54 & 65.46 \\
1995 & 6.96 & 2.65 & 21.99 & 31.60 & 68.40 \\
1998 & 7.74 & 2.82 & 21.19 & 31.75 & 68.25 \\
2001 & 7.82 & 2.98 & 22.08 & 32.89 & 67.11 \\
2005 & 7.87 & 3.43 & 24.12 & 35.43 & 64.57 \\
2008 & 8.53 & 3.47 & 26.99 & 38.99 & 61.01 \\
2011 & 9.38 & 3.32 & 29.23 & 41.94 & 58.06 \\
Var. 2011/1988 & $\mathbf{6 5 . 5 9}$ & $\mathbf{7 5 . 4 5}$ & $\mathbf{2 9 . 3 9}$ & $\mathbf{3 9 . 0 9}$ & $\mathbf{- 1 6 . 8 7}$ \\
Var. 2011/1982 & $\mathbf{8 7 . 2 3}$ & $\mathbf{1 3 1 . 1 1}$ & $\mathbf{4 5 . 5 4}$ & $\mathbf{5 8 . 0 5}$ & $\mathbf{- 2 0 . 9 6}$ \\
\hline
\end{tabular}

Source: Pnad/IBGE, several years.

forms compared to those observed in other regions. For example, while coverage due to retirement in the North is only $5.7 \%$ in 2011 , this same statistic is $11.2 \%$ in the South, for the same year. Similarly, while coverage in South and Southeast due to contributory membership in 2011 stood close to 35\% in the North and Northeast these values were less than $20 \%$.

In terms of growth pace there are also large differences between regions of the country. The contributory membership rate, for example, showed an increase over 65\% in the Northeast, South and Midwest, from 1982 to 2011, whereas In the Southeast, this growth was $34.9 \%$ and in the North of only $2.5 \%$. It is also in the North Region that one can find the lowest rates of expansion of pension coverage in all forms and the lowest overall rate of direct pension coverage as well.

In the same period, while the national average expansion of pension coverage due to retirement was $87.2 \%$ in the North was only $58.0 \%$. The increase in the coverage due to pension, in Brazil was $131.1 \%$ but in the North it was of only $43.8 \%$. Considering the very low performance of all forms of direct coverage in the North Regionbelow the national average - the direct coverage in the North region were the lowest in the country and that which growth is the lesser over the past almost 30 years. Table 7 presents this information.

From the perspective of the gender, there is a significant advancement of direct pension coverage among women. In 1982, only $17.9 \%$ of the women had social security direct coverage. In 2011, that number was more than double: 38.1\%. Decomposing the direct total coverage, it is observed that, with the exception of coverage by pension, the pace of increase in coverage among women has occurred more rapidly than among men. Among women, the pension coverage by retirement between 1982 and 2011 increased from 3.7\% to 8.4\%. Among men, this coverage increased from $6.4 \%$ to $10.5 \%$. The same applies to the coverage by contribution. Although women are still at a level very lower than that of men (21.8\% versus $32.5 \%)$, the expansion speed of coverage for women happened in a pace more pronounced. On average, women increased their coverage by contributions at a rate 5 times higher than that for men throughout the period considered. In the case of pensions, the reverse process occurred. The pace of expansion for men was higher. But still, given the characteristics of this benefit, coverage among women is more than 7 times higher than for men yet.

It should also be noted that this expansion of coverage of women is continuous throughout the period, and even before the Constitution of 1988, the rate of expansion of coverage was high, and, in fact, $76 \%$ higher than that observed in the post-Constitution period. This occurs in all of the three possible ways of coverage. The expansion of coverage for women is a process previous of the 1988 Constitution. The 1988 Constitution may have assisted in the expansion of social security protection given to women, but it is not the origin, neither the main cause of coverage expansion for women (Table 8). 
Table 7. Incidence of direct pension coverage by type, and region-selected years.

\begin{tabular}{|c|c|c|c|c|c|c|}
\hline Year & Region & $\begin{array}{c}\text { Coverage by } \\
\text { retirement }\end{array}$ & $\begin{array}{c}\text { Coverage } \\
\text { by pension }\end{array}$ & $\begin{array}{l}\text { Coverage by } \\
\text { contribution }\end{array}$ & $\begin{array}{c}\text { Total direct } \\
\text { coverage }\end{array}$ & $\begin{array}{c}\text { Not direct } \\
\text { coverage }\end{array}$ \\
\hline \multirow{6}{*}{1982} & Brazil & 5.01 & 1.44 & 20.09 & 26.53 & 73.47 \\
\hline & North & 3.58 & 1.23 & 18.77 & 23.58 & 76.42 \\
\hline & Northeast & 5.04 & 0.82 & 10.94 & 16.79 & 83.21 \\
\hline & Southeast & 5.35 & 1.96 & 25.91 & 33.22 & 66.78 \\
\hline & South & 4.93 & 1.48 & 21.83 & 28.24 & 71.76 \\
\hline & Center-West & 3.41 & 0.68 & 18.35 & 22.43 & 77.57 \\
\hline \multirow{6}{*}{1988} & Brazil & 5.67 & 1.89 & 22.59 & 30.15 & 69.85 \\
\hline & North & 3.79 & 1.30 & 19.42 & 24.51 & 75.49 \\
\hline & Northeast & 5.79 & 1.19 & 12.88 & 19.87 & 80.13 \\
\hline & Southeast & 5.98 & 2.50 & 28.74 & 37.22 & 62.78 \\
\hline & South & 5.78 & 1.93 & 24.50 & 32.20 & 67.80 \\
\hline & Center-West & 3.74 & 1.18 & 21.24 & 26.17 & 73.83 \\
\hline \multirow{6}{*}{2011} & Brazil & 9.38 & 3.32 & 29.23 & 41.94 & 58.06 \\
\hline & North & 5.66 & 1.77 & 19.23 & 26.66 & 73.34 \\
\hline & Northeast & 9.32 & 2.85 & 18.93 & 31.10 & 68.90 \\
\hline & Southeast & 9.96 & 3.73 & 34.94 & 48.64 & 51.36 \\
\hline & South & 11.20 & 4.34 & 36.45 & 51.99 & 48.01 \\
\hline & Center-West & 7.07 & 2.59 & 32.93 & 42.59 & 57.41 \\
\hline \multirow{6}{*}{$\begin{array}{c}\text { Var. (\%) } \\
\text { 2011/1982 }\end{array}$} & Brazil & 87.23 & 131.11 & 45.54 & 58.05 & -20.96 \\
\hline & North & 57.98 & 43.83 & 2.46 & 13.06 & -4.03 \\
\hline & Northeast & 85.16 & 249.18 & 73.05 & 85.23 & -17.20 \\
\hline & Southeast & 86.08 & 90.11 & 34.88 & 46.39 & -23.08 \\
\hline & South & 127.45 & 193.19 & 66.94 & 84.11 & -33.10 \\
\hline & Center-West & 107.51 & 279.38 & 79.52 & 89.84 & -25.98 \\
\hline
\end{tabular}

Source: Pnad/IBGE, several years.

Table 8. Incidence of direct pension coverage by type and by gender-Brazil: 1982-2011.

\begin{tabular}{cccccccccccc}
\hline & \multicolumn{2}{c}{$\begin{array}{c}\text { Coverage by } \\
\text { Years }\end{array}$} & \multicolumn{2}{c}{$\begin{array}{c}\text { Coverage } \\
\text { retirement }\end{array}$} & \multicolumn{2}{c}{$\begin{array}{c}\text { Coverage by } \\
\text { contribution }\end{array}$} & \multicolumn{2}{c}{ Total coverage } & \multicolumn{2}{c}{ Not direct coverage } \\
\cline { 2 - 12 } & Male & Female & Male & Female & Male & Female & Male & Female & Male & Female \\
\hline 1982 & 6.35 & 3.70 & 0.21 & 2.64 & 28.80 & 11.52 & 35.35 & 17.86 & 64.65 & 82.14 \\
1988 & 6.94 & 4.44 & 0.23 & 3.49 & 30.89 & 14.59 & 38.06 & 22.53 & 61.94 & 77.47 \\
1993 & 7.92 & 5.27 & 0.27 & 4.30 & 28.89 & 14.71 & 37.08 & 24.28 & 62.92 & 75.72 \\
1997 & 8.96 & 6.05 & 0.40 & 4.97 & 27.76 & 15.90 & 37.12 & 26.92 & 62.88 & 73.08 \\
2001 & 9.25 & 6.47 & 0.53 & 5.30 & 27.38 & 17.07 & 37.16 & 28.84 & 62.84 & 71.16 \\
2005 & 9.34 & 6.48 & 0.72 & 6.02 & 29.29 & 19.21 & 39.35 & 31.70 & 60.65 & 68.30 \\
2009 & 9.99 & 7.31 & 0.97 & 6.02 & 33.02 & 22.54 & 43.99 & 35.87 & 56.01 & 64.13 \\
2011 & 10.46 & 8.37 & 0.91 & 5.59 & 34.60 & 24.17 & 45.98 & 38.13 & 54.02 & 61.87 \\
Var. $2011 / 1982$ & $\mathbf{6 4 . 8 5}$ & $\mathbf{1 2 6 . 1 3}$ & $\mathbf{3 3 5 . 5 6}$ & $\mathbf{1 1 1 . 5 5}$ & $\mathbf{2 0 . 1 7}$ & $\mathbf{1 0 9 . 7 9}$ & $\mathbf{3 0 . 0 5}$ & $\mathbf{1 1 3 . 4 4}$ & $\mathbf{- 1 6 . 4 3}$ & $\mathbf{- 2 4 . 6 7}$ \\
\hline
\end{tabular}

Source: Pnad/IBGE, several years. 
Another important dimension of social security coverage refers to the individual's age. The direct coverage is very different according to age. Children and young people, a group that will be carefully analyzed ahead, have low direct social security coverage. The direct coverage for children and young people which were very low in 1982 fell by half in 2008. And that was basically due to the reduction in coverage by contribution. At same time it reveals a social advancement, since relatively fewer children and adolescents are in the labor market.

At the other side of the age distribution, it appears that direct coverage of the group of 60 or more increased from $67.4 \%$ in 1982 to $82.3 \%$ in 2011. This growth was not higher because there was a slight reduction of 2 percentage points in coverage due to contributory membership. In summary, the expansion of social security coverage for this age group was motivated solely by the expansion of granting social security benefits.

For economically active age group (individuals between 16 and 59 years) pension coverage expanded from $40.6 \%$ in 1982 to $50.8 \%$. In 2011.This increase is almost equally split between granting of benefits and membership contribution ( $58 \%$ for the first and $42 \%$ for the second). Table 9 summarizes this information.

\subsection{The Total Social Security Coverage: Definition}

Brazilian law provides that spouses and children or stepchildren under age 21 are potentially protected. The statistic of coverage that incorporates these segments provides a more accurate picture of the extent of the Brazilian social security system, in terms of protected population and it also allows the identification of social groups more exposed to social unprotection risk and its measurement

The construction of direct plus indirect coverage variable was made through the "extension" of direct coverage to members of the family unit, according to each type of coverage. So for example, if the reference person in the family unit (or your spouse) has pension coverage by contributing to social security, your spouse, your children or stepchildren under age 21 also have pension coverage. The same applies if the reference person or spouse receives benefits (retirement or pension).

\section{The Social Security as a Way for Reducing Poverty and Inequality}

Some analysts consider social security as a social program to ensure to all old individual a non-contributory benefit. Sometimes this idea is complemented by the understanding that social security should be a redistributive welfare system in which the contributions are payable upon availability of each individual and the benefits received according to their need [2-4].

Two of the arguments most often used for supporting the idea of a welfare system as a "minimum income program”, or as a non-contributory program, are 1) the fact that social security system is a powerful instrument for reducing poverty and social inequality, both individual and household, and 2) it is a necessary guarantee of income against the labor market high informality. Both arguments are true. But they have serious limitations.

Table 9. Incidence of direct pension coverage by type and by age group-Brazil: 1982-2011.

\begin{tabular}{cccccc}
\hline \multirow{2}{*}{ Year } & \multicolumn{5}{c}{ People who have social security protection } \\
\cline { 2 - 6 } & Up to 15 years & 16 thru 59 years & 16 thru 59 benefits & 60 years and over & 60 years and over benefits \\
1982 & 0.59 & 40.76 & 4.57 & 67.36 & 60.62 \\
1988 & 0.88 & 44.52 & 5.06 & 72.23 & 65.53 \\
1990 & 0.97 & 51.00 & 5.24 & 74.86 & 67.46 \\
1995 & 0.64 & 43.11 & 5.65 & 80.71 & 76.02 \\
1999 & 0.32 & 41.05 & 6.21 & 81.27 & 76.95 \\
2005 & 0.15 & 44.11 & 5.77 & 82.48 & 78.16 \\
2008 & 0.21 & 47.82 & 5.46 & 82.03 & 77.18 \\
2011 & 0.26 & 50.84 & 5.43 & 82.34 & 76.75 \\
Var. 2011/1982 & $-\mathbf{5 5 . 7 3}$ & $\mathbf{2 4 . 7 2}$ & $\mathbf{1 8 . 7 4}$ & $\mathbf{2 2 . 2 3}$ & $\mathbf{2 6 . 6 2}$ \\
\hline
\end{tabular}

Source: Pnad/IBGE, several years. 
It seems a consensus among analysts that the welfare-there including assistance component—acts strongly on poverty reduction and on individual and household inequality as well. In fact, after the payment of pensions for families, poverty is reduced, as can be seen in Figure 3.

The effectiveness of the instrument as reducing poverty was accelerated until 2002, but stopped growing and fell slightly thereafter. In 1992, it reduced the incidence of poverty by 10.9 percentage points (from $50.4 \%$ to $39.5 \%$ ) and in 2003 , the reduction was 7.8 percentage points (from $43.6 \%$ to $35.8 \%$ ). But in 2009, poverty reduction was 6.1 percentage points, corresponding to a drop of $22.2 \%$.

The initial increase was due to two simultaneous factors: on the one hand, the increase of issued benefits which happened at a very high pace, especially those of minimum value, known as "floor benefit". The second factor was the growing in the real value of the benefit that started in the second half of the mid-90. However, recent years reveal the weakening of the instrument.

The fact that the social security is an instrument for reducing poverty does imply neither that it is efficiently used nor that it is acting on the poorest. To do so, it is enough simply indicate that if two poor individuals, one being poorer than the other, and if the public policy allocate resources to the less poor, poverty will certainly decrease but it will not reach the poorest, and so it will not reach its maximum power. Therefore, reducing poverty does not necessarily mean protect the poorest, but only the poor. Indeed, Barros and Carvalho [5] showed that: 1) only three out of ten welfare recipients who receive the minimum wage live in poor family ( 7 in ten are out of poverty), and 2) that the minimum wage is between 3 and 4 times less effective in reducing poverty than a targeted program (such as Bolsa Família, BF, for example) and, consequently, is nearly four times more expensive than this program to achieve the same goal.

Now, if the desirable goal is reducing poverty, then definitely the social security is not the best tool, because as it is designed it is expensive, discourages the contribution, and subverts the concept of social insurance. Just as an exercise, it would be possible to devise a program of income transfer focused on the poorest, in the shape of BF. For comparison, the exercise is done by keeping constant the amount of resources transferred by social security. If the program was focused on the most deprived segments of income, the impact on poverty reduction would be much more intense than by social security, as shown in the Figure 4.

A second aspect of the question concerns to the ability of social security to reduce household poverty, particularly among children and young people. An argument often used is that the elderly who receive an income from the pension system share it in household. However, if this assertion were true, this would imply that the incidence of poverty would be invariant with age. If so, the incidence of poverty among children and young people could not be higher than among the elderly. However, that is not what happens in Brazil.

The incidence of poverty among children and youth (under 18 years) is more than three times higher than among elderly (aged 65 and over). That is far from what was envisioned by the proponents of the idea of soli-

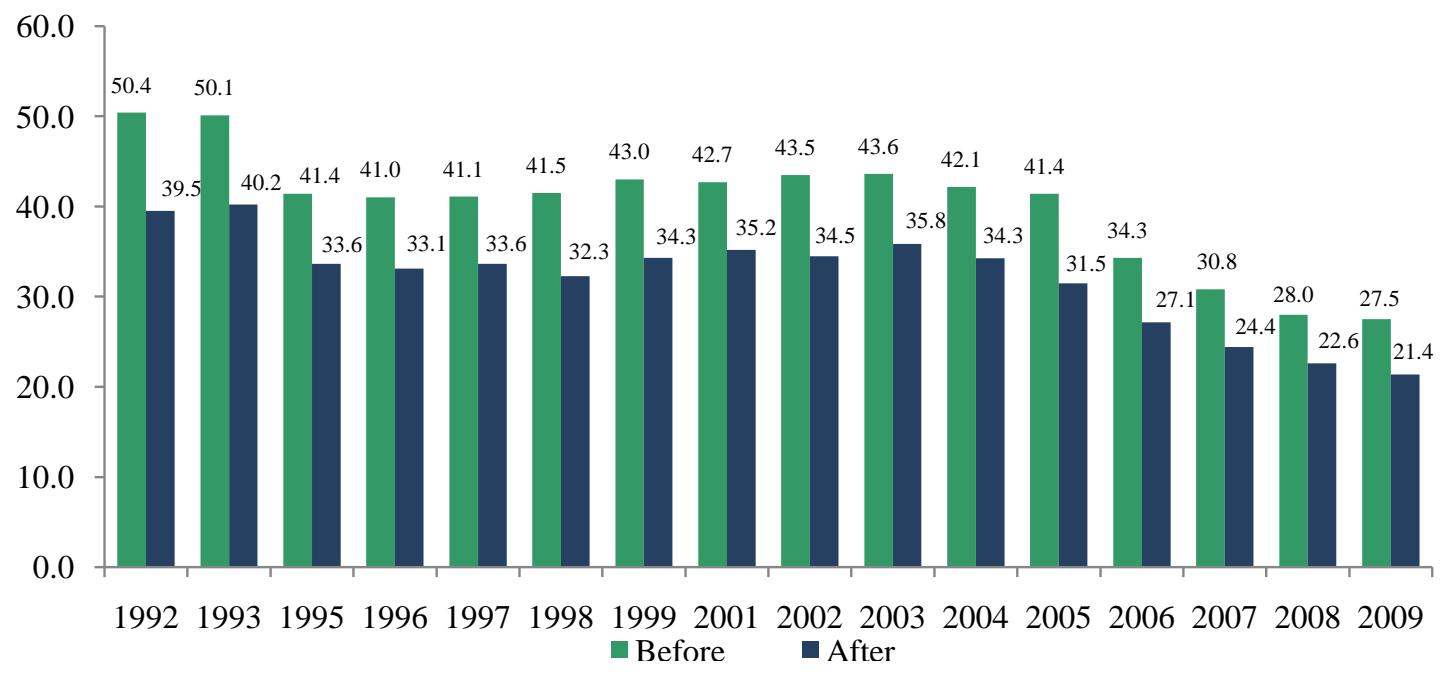

Figure 3. Household poverty before and after payment of social security benefits (in\%)-Brazil: 1992-2009, Source: Pnad/IBGE several years. Prepared by Tafner (2007) and updated by the authors. 


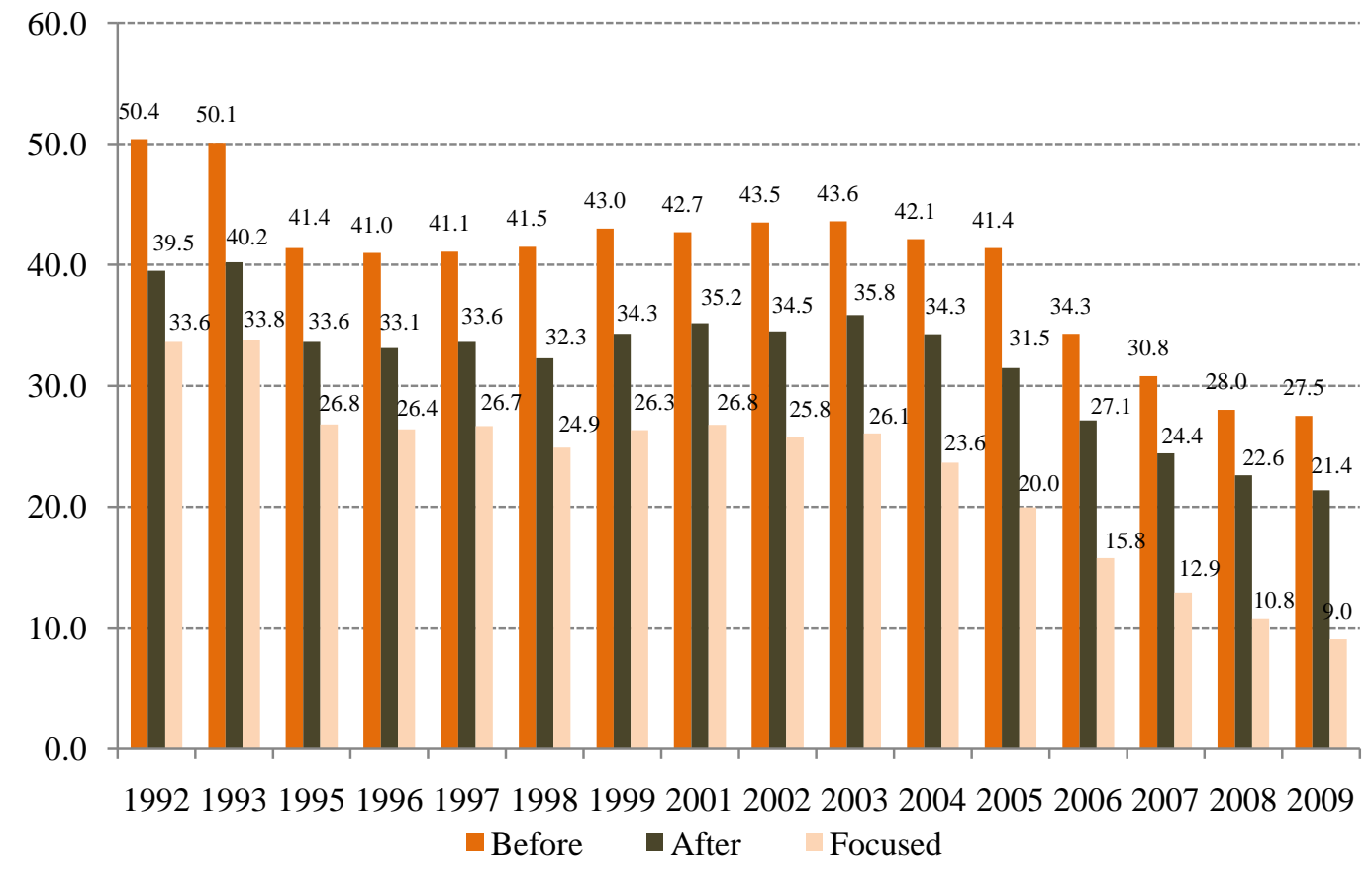

Figure 4. Household poverty before and after payment of social security benefits and the simulation of a focused income distribution program among the poorest (in\%)-Brazil: 1992-2009, Source: Pnad/IBGE: prepared by Tafner (2007), several years and updated by the authors.

darity between generations. It also means that the income transferred from social security does not provide significant benefits for children and youth. Table 10 presents some important information concerning to the condition of these groups such as per capita income, poverty, extreme poverty and wage.

From this information we may say that the social security is reducing the high level of poverty in the country. Nevertheless, this does not means that the instrument is focusing on the poorest. As just shown, social security resources do not circulate between generations in order to promote a balance for all ages. If we wanted social security as a redistributive program, we should draw it transferring resources to the poorest-young people and children.

Barros and Carvalho [5] showed that if $20 \%$ of the total transferred to the elderly, were instead transferred to youngest people, poverty would be reduced by almost $10 \%$ percentage points—and $13 \%$ among children. By doing so, poverty among the elderly would increase only $3 \%$. In aggregate terms, this would reduce poverty in Brazil 4 percentage points.

The evidence reveal that the argument that social security should be kept as it is now because it is a mechanism to transfer income is flawed. And this is because two reason: first, because the foundation of social security in Brazil, as in many countries, is social insurance, which means that the system is a contract in which each individual agrees to pay a portion of their income to support the system and then when he loses the ability to work, get the right to be supported by social security; and secondly because who is a beneficiary of welfare system is not the poorest. It is more appropriate, therefore overcome the problems of social security system and improve social programs, focusing resources and attention on the poor, with priority assistance to the poorest.

\section{Challenges}

An important aspect of Brazilian social security refers to the welfare coverage. The rate of expanded welfare coverage (direct plus indirect) is approximately $71 \%$ of the population which, according to many analysts is low. It would be even lower if the granting of benefits post-CF-1988 had not been so high. Using data from PNAD 1982 and applying the same criteria used in Table 5, surprisingly we find out same result: 71\% of the population was already covered before CF-1988. What changed, and changed a lot, is the coverage composition. In summary: by one hand we extended coverage (by granting benefits) to all individuals over 60 years and by other the 
social protection for children and young people has been reduced (Table 11).

Once obtained the coverage rate, one may determine its symmetrical named as "no coverage rate. Doing this by age (and not by age group), the "no-coverage" rate for children and young people is up to 5 times higher than among elderly (above 60 years). And what is even worse: between 1982 and 2011 the "no-coverage" rate has increased from 38.9\% to 40.4\%, as shown in Table 11. As known, children and teens, in general, have young adult as parents. If young and teens have no welfare protection this is because their parents are also unprotected. A policy that brings youth and young adults in to the formal labor market is needed. This is the way to assure welfare protection to children and youth in Brazil. This need is even more urgent because almost half of working age people are out of welfare protection.

Young adults in Brazil have been systematically excluded from access to positions that allow them to have conditions of autonomous life. The welfare no-protection is at same time a cause and a consequence of this serious social situation. Young adults that are excluded from the formal labor market have their children also ex-

Table 10. Per capita household income, household poverty and income below minimum wage-Brazil 2011.

\begin{tabular}{ccccc}
\hline Age & $\begin{array}{c}\text { Per capita monthly } \\
\text { household income (in R\$) }\end{array}$ & $\begin{array}{c}\text { Poverty } \\
\text { incidence (\%) }\end{array}$ & $\begin{array}{c}\text { Extremely poverty } \\
\text { incidence (\%) }\end{array}$ & $\begin{array}{c}\text { Percentage of individuals with } \\
\text { remuneration below minimum wage }\end{array}$ \\
\hline 15 & 504 & 32.9 & 12.3 & 90.9 \\
16 & 521 & 29.7 & 11.4 & 81.2 \\
17 & 550 & 27.8 & 10.8 & 58.6 \\
18 & 583 & 26.0 & 10.1 & 43.6 \\
19 & 605 & 22.3 & 8.3 & 39.4 \\
20 & 674 & 20.0 & 8.2 & 35.4 \\
21 & 676 & 19.7 & 8.0 & 32.6 \\
22 & 704 & 19.7 & 8.2 & 30.0 \\
23 & 738 & 19.6 & 8.1 & 28.5 \\
24 & 766 & 18.9 & 7.5 & n.a \\
0 to 14 & 468 & 38.4 & 15.0 & 42.8 \\
15 to 24 & 629 & 23.9 & 9.4 & 24.1 \\
25 and over & 902 & 15.1 & 5.3 & \\
\hline
\end{tabular}

Source: Pnad/IBGE.

Table 11. Direct and indirect coverage in the Brazilian social security system-1982 and 2011 (\%).

\begin{tabular}{|c|c|c|c|c|c|c|c|c|}
\hline Age group & $\begin{array}{l}\text { Under } 15 \\
\text { years }\end{array}$ & $\begin{array}{c}15 \text { to } 59 \\
\text { years }\end{array}$ & $\begin{array}{c}60 \text { to } 69 \\
\text { years }\end{array}$ & $\begin{array}{c}70 \text { years and } \\
\text { over }\end{array}$ & $\begin{array}{c}\text { Under } 15 \\
\text { years }\end{array}$ & $\begin{array}{c}15 \text { to } 59 \\
\text { years }\end{array}$ & $\begin{array}{c}60 \text { to } 69 \\
\text { years }\end{array}$ & $\begin{array}{c}70 \text { years and } \\
\text { over }\end{array}$ \\
\hline Direct coverage (A) & 0.22 & 39.41 & 58.25 & 81.83 & 0.16 & 49.44 & 76.90 & 89.12 \\
\hline Indirect coverage (B) & 60.94 & 29.31 & 22.08 & 9.68 & 59.41 & 23.01 & 13.73 & 5.68 \\
\hline By pension & 1.75 & 0.63 & 1.16 & 0.50 & 1.73 & 0.63 & 1.37 & 0.88 \\
\hline By contribution & 55.15 & 23.65 & 9.14 & 1.62 & 55.53 & 18.12 & 5.31 & 1.13 \\
\hline
\end{tabular}

Source: Pnad/IBGE. 
cluded from social protection, producing a perverse cycle of poverty that is repeated for generations. Promoting a set of institutional reforms dealing with welfare exclusion seems to be an urgent political agenda in Brazil.

\section{Conclusions}

In the last three decades, many countries have reformed their pension systems. These reforms were the response to the inadequacy of their institutional framework which was not adapted to demographic, economic and social changes that occurred in the 20th century boosted spending and eroded the base funding of social security systems. Brazil, nearly 30 years ago, also undertook a reform (later amended in 1998 and 2003) facing the same challenges. These reforms, however, were partial and incomplete, so a new round of adjustments will be required.

A new round of reforms probably raises into citizens a sense of permanent change of rules. And this feeling tends to raise political resistance to change. This resistance reflects the imbalance between losses and gains, between present and future, and it is often a result of absence of precise information which induces people to have prejudices and wrong ideas. To a large extent this is because reforms involve technical particularities, diverse social and political actors, and different costs and penalties, according to age, gender, economic activity and life plans. For all social groups, however, changing pension rules means taking losses in the present to avoid bigger losses in the future

A new round of institutional reforms probably raises into citizens a sense of permanent change of rules. And this feeling is likely to raise social and political resistance to change. This resistance largely reflects the imbalance between losses and gains, between present and future, and it is often a result of absence of precise information which allows people make up correct ideas devoid of prejudices. This, far from being a Brazilian peculiarity, is the norm in most countries. To a large extent this is because doing pension reform requires technical particularities, diverse social and political actors and different costs and penalties, according to age, gender, economic activity and life plans. For all social groups, however, changing pension rules means taking losses in the present to avoid bigger losses in the future.

Another important aspect is that, as the reforms involve several minor operational adjustments-like changing age for entitling the benefit, contribution period, the benefit amount, and conditions for termination-a particular change may cause loss to some, but being neutral for others. In general, vetoes for this kind of change are strongly preferred by small groups, producing various minorities with strong opposition.

Overcoming resistance and generate a set of minimum acceptance parameters takes time. Besides that, there must be broad technical information in order to guide the debate on more substantive issues. Technical information are important because they allow parties understand and make calculation, including those in absence of reforms. The explanation of the trade-offs is essential to move forward. And that takes time.

In Brazil, poverty and extreme poverty are restricted to groups of children and youth. As shown by Tafner, Carvalho and Botelho [6], an individual with up to 20 years of age is ten times more likely to be extremely poor than an individual aged 60 or more. In addition, three quarters of federal social spending goes to Social Security (nearly 9\% of GDP), while the Bolsa Família Program, for example, which has proved be more effective in reducing poverty and destitution in the country, consumes less than $0.5 \%$ of GDP. In 2011, for instance, more than $95 \%$ of individuals aged 60 or older were protected by Social Security, but among children and young, less than two thirds were protected. The remaining individuals (almost 30 million) were with no protection at all. If nothing is changed, the effects can be harmful to particular groups, particularly young people. It is well known that the difficulties they face in entering the formal labor market may reduce the social protection for this group. The result, in terms of social problems, is a huge amount of children and young people living in poverty, reproducing a cycle of poverty that affects not only the group itself, but its future generations. It also affects the society, since there are many negative externalities in this situation.

The main purpose of this paper is to provide some information that could contribute to the debate on the pension system. We also show that Brazilian Social Security System has accumulated serious imbalances, making pressure on government accounts with negative impacts on the long-term possibilities of growth.

\section{References}

[1] Giambiagi, F. and Tafner, P. (2010) Demographics—The invisible threat: The pension dilemma that Brazil must face. 
Rio de Janeiro. Elsevier.

[2] Delgado, G. and Cardoso Jr., J.C. (2000) Universalization of minimum social rights in Brazil: The case of rural welfare in the 90s. In: Social Security, welfare and poverty alleviation. MPAS, Brasilia.

[3] Delgado, G.C. (2005) Social policy and income distribution in Brazil. In Seminar: Wages and Development. IE/Unicamp, Campinas.

[4] Lavinas, L. (2006) From means-test schemes to basic income in Brazil: Exceptionality and paradox. International Social Security Review, 59, 103-125. http://dx.doi.org/10.1111/j.1468-246X.2006.00249.x

[5] Barros, R.P. and Carvalho, M. (2005) Minimum wage and income distribution. IPEA Set, Rio de Janeiro.

[6] Tafner, P., Carvalho, M. and Botelho, C. (2009) The improvement of social policies towards the Bolsa Família in Brazil 2.0 post-Crisis-agenda for the next decade. Rio de Janeiro, Elsevier. 


\section{Annex}

Population by age group (million) - Brazil: 1980

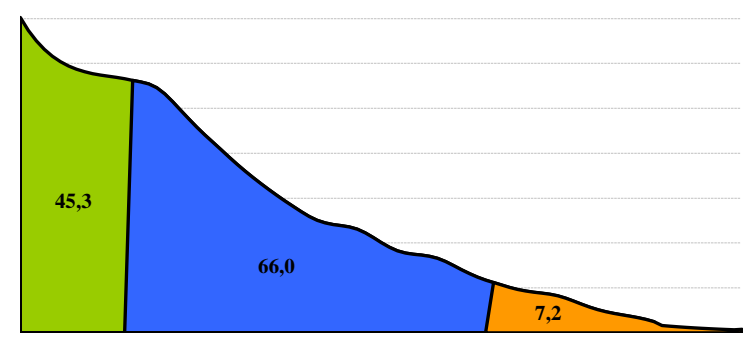

口Up to 14 years

$\mathbf{\square} 15$ to 59 years

D60 years and over

Population by age group (million) - Brazil: 1990

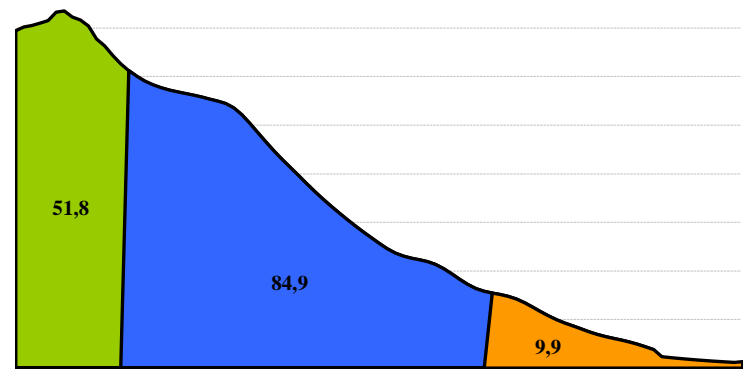

口Up to 14 years $\quad \mathbf{\square} 15$ to 59 years $\mathbf{\square} 60$ years and over

Population by age group (million) - Brazil: 2000

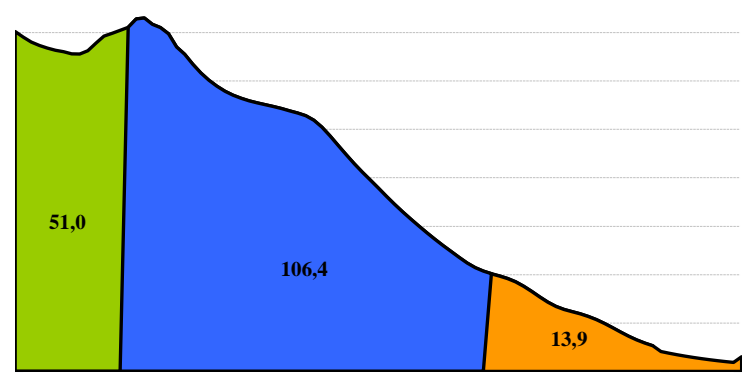

口Up to 14 years

$\mathbf{\square} 15$ to 59 years

口60 years and over

Population by age group (million) - Brazil: 2010

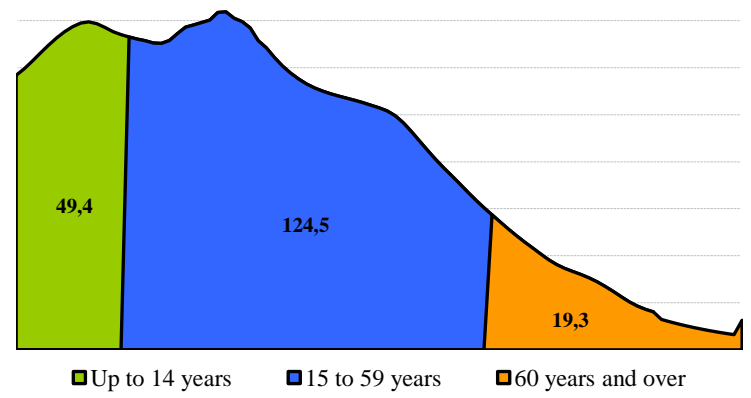

Figure A1. Demographic changes in Brazil-1980-2050s.
Population by age group (million) - Brazil: 2020

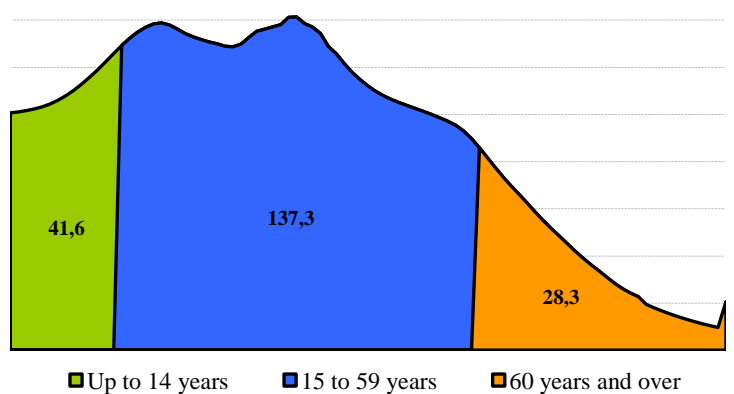

Population by age group (million) - Brazil: 2030

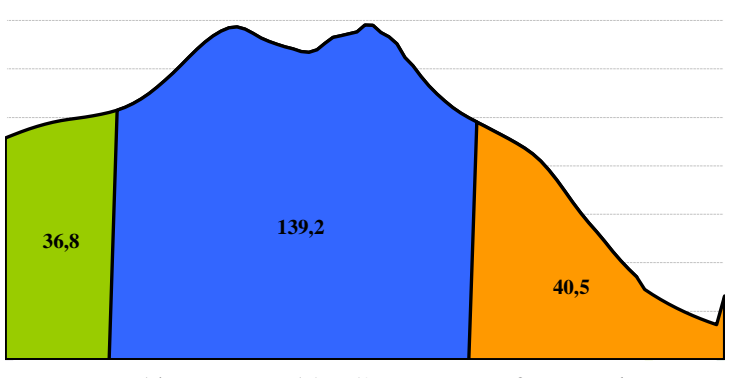

DUp to 14 years $\mathbf{\square} 15$ to 59 years $\mathbf{0} 60$ years and over

Population by age group (million) - Brazil: 2040

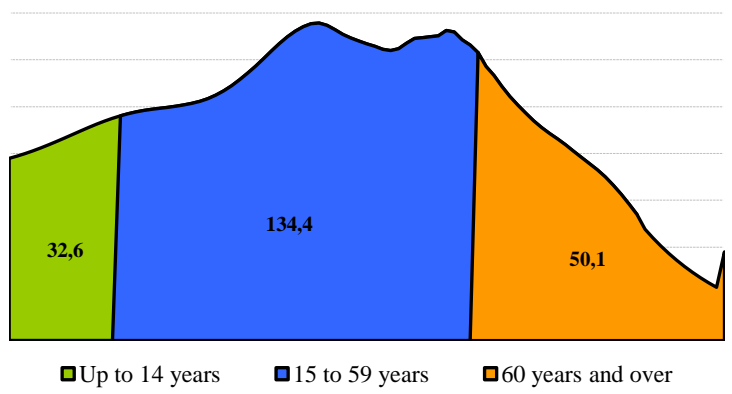

Population by age group (million) - Brazil: 2050

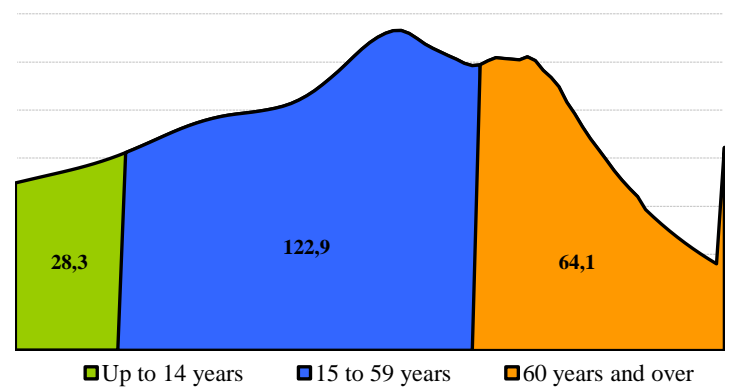

